\title{
RESEARCH
}

Open Access

\section{Effects of dyslipidemia on E antigen seroconversion of patients with chronic hepatitis $B$ treated by nucleoside (acid) analogs}

Ziqiang Xia ${ }^{1}$, Juzeng Zheng ${ }^{2}$, Liang Zheng ${ }^{1}$, Endian Zheng ${ }^{1}$, Zhuolin Zou ${ }^{3,4}$, Xiong Sheng ${ }^{3,4^{*}}$ and Jinming $\mathrm{Wu}^{2^{*}}$

\begin{abstract}
Background: The prevalence of dyslipidemia in China is increasing annually. Current studies suggest that dyslipidemia affects the antiviral efficacy of hepatitis $\mathrm{C}$ virus (HCV) therapies, while recent studies suggest that serum lipids influence the response rates of chronic hepatitis B (CHB) patients receiving PEGylated interferon-alpha (Peg IFN-a) treatment. However, the role of dyslipidemia in the efficacy of nucleoside (acid) analogues (NAs) in CHB patients remains unclear.

Methods: From January 2010 to December 2013, data from 179 treatment-naive patients with CHB who were hepatitis B e antigen (HBeAg)-positive and had visited the first affiliated hospital of Wenzhou Medical University were assessed. Of these patients, 68 were assigned to the dyslipidemia group (diagnosed with CHB complicated with dyslipidemia) and 111 to the normolipidemic group. The following 3 treatment strategies were performed for all CHB patients over a 5-year period: lamivudine (LAM) plus adefovir dipivoxil (ADV) combination therapy, telbivudine (LdT) monotherapy, and entecavir (ETV) monotherapy. Serum assessments, blood biochemistry, HBV serological markers, HBV DNA before treatment and HBeAg serological conversion and virological responses at different timepoints after treatment were compared between the two groups. Measurement data were compared by $\tau$ tests and enumeration data by $x^{2}$ tests. Correlation analysis was performed using binary logistic regression analysis.
\end{abstract}

\footnotetext{
* Correspondence: 783532291@qq.com; wzfydw@163.com

${ }^{3}$ Department of Infectious Diseases, The First Affiliated Hospital of Jiaxing College, Jiaxing 314000, China

2Department of Gastroenterology, The First Affiliated Hospital of Wenzhou Medical University, Wenzhou 325000, China

Full list of author information is available at the end of the article
}

(c) The Author(s). 2021 Open Access This article is licensed under a Creative Commons Attribution 4.0 International License, which permits use, sharing, adaptation, distribution and reproduction in any medium or format, as long as you give appropriate credit to the original author(s) and the source, provide a link to the Creative Commons licence, and indicate if changes were made. The images or other third party material in this article are included in the article's Creative Commons licence, unless indicated otherwise in a credit line to the material. If material is not included in the article's Creative Commons licence and your intended use is not permitted by statutory regulation or exceeds the permitted use, you will need to obtain permission directly from the copyright holder. To view a copy of this licence, visit http://creativecommons.org/licenses/by/4.0/. The Creative Commons Public Domain Dedication waiver (http://creativecommons.org/publicdomain/zero/1.0/) applies to the data made available in this article, unless otherwise stated in a credit line to the data. 
Results: The rates of HBeAg seroconversion in the dyslipidemia group at years 1, 2, 3, and 4 were 10.3, 13.2, 17.6, and $22.1 \%$, respectively, which were not significantly lower than those of the normolipidemic group $(11.7,16.2,18.0$ and 33.3\%; $X^{2}=0.085,0.293,0.004$, and 2.601, respectively; $\left.P>0.05\right)$. However, the rates of HBeAg seroconversion in the dyslipidemia group were significantly lower than those in the normolipidemic group at year 5 (27.9\% vs. 43.2\%, $\left.X^{2}=4.216, P<0.05\right)$. Univariate logistic regression analysis revealed significant differences in group, gender, PTA, ALT, AST, CR, and LDL-C between groups with and without seroconversion. Multivariate regression analysis demonstrated that dyslipidemia $(\mathrm{OR}=1.993, P=0.038)$ and male gender $(\mathrm{OR}=2.317, P=0.029)$ were risk factors associated with HBeAg seroconversion.

Conclusions: During antiviral therapy, dyslipidemia affects HBeAg seroconversion in CHB patients treated with NAs, but does not affect the virological response.

Keywords: Dyslipidemia, Chronic hepatitis B, Nucleoside (acid) analogs, Antiviral effect

\section{Introduction}

Chronic hepatitis B virus (HBV) infection is known to be a major risk factor for hepatocellular carcinoma (HCC) [1]. As per WHO estimates, 296 million people were living with chronic hepatitis B infection in 2019, and $\sim 1.5$ million new HBV infections are recorded each year. In 2019, hepatitis B accounted for $\sim 820,000$ deaths, which were majorly contributed by cirrhosis and hepatocellular carcinoma (primary liver cancer) [2]. Interestingly, China alone accounts for nearly half of the global disease burden for chronic HBV. Despite free administration of the hepatitis $B$ vaccine, $~ 93$ million individuals are still infected with chronic HBV in China, which includes $\sim 20$ million patients with chronic hepatitis B (CHB) [3]. Currently, no effective therapies are available to ensure a complete recovery from HBV infection. Once HBV enters the liver cells, it delivers its covalently closed circular DNA (cccDNA) genome. This cccDNA genome is endowed with a long half-life and self-renewal capacity, which protects it against elimination. In addition to these, the unavailability of direct therapeutics further prevents the elimination of cccDNA. Thus, the persistent existence of cccDNA integrating HBV DNA and impairment of innate and specific immunity make the clearance of chronic HBV infection quite difficult.

HBeAg is a non-structural protein that is encoded by the pre- $C / C$ gene. It acts as a serum antigen marker after hepatitis $B$ infection. In particular, $\mathrm{HBeAg}$ reflects active replication of hepatitis $B$ virus, with the presence of a solid infectious state. Following $\mathrm{HBeAg}$ seroconversion, certain patients exhibit a low replication phase, which is characterized by normal serum ALT concentration and minimal liver histological changes, suggesting slower liver damage [4]. Thus, seroconversion is utilized as the target in HBeAg-positive CHB patients.

Interferon (IFNs) and nucleoside (acid) analogs (NAs) can efficiently inhibit HBV replication and reduce the incidence of liver cirrhosis, hepatic failure, and hepatocellular carcinoma (HCC) [5]. In particular, NAs act via inhibition of reverse transcription of pre-genome RNA and HBV DNA synthesis in the cytoplasm. However, these molecules do not exert any influence on HBV cccDNA directly. In comparison to this, interferon promotes host immune defenses against HBV, however, the precise mechanism of the same remains unknown. Recent studies showed that in comparison to NAs, IFNs promoted the degradation of cccDNA and lead to epigenetic modifications in the transcription of cccDNA [6]. Despite their effective activity, the therapeutic applications of common IFN and PEG IFN are quite limited, and their use is prohibited in patients with uncompensated cirrhosis of the liver, acute exacerbation of chronic hepatitis, autoimmune disease, or mental illness. NAs are widely used in China, but these molecules exhibit low efficacy.

With the advancement of the national economy in China, there has been an annual increase in the prevalence of dyslipidemia in the Chinese population. In general, dyslipidemia refers to an increase in the levels of cholesterol (TC) and/or triglycerides (TG) in the serum. Additionally, it also refers to various dyslipidemia states involving symptoms of low-high density lipoprotein cholesterol (HDL-C) in the blood [7]. So far, lipid metabolism as a consequence of chronic HBV infection has been well characterized [8-10]. One of the previous studies showed that the expression of HBV in transgenic mice altered lipid metabolism, and induced oxidative stress in the liver [9]. In another study, it was reported that HBV infection could induce the expression of genes involved in cholesterol synthesis, and thus promoted cholesterol production [11]. Additionally, HBV X protein has been previously shown to inhibit the secretion of apolipoprotein B (Apo-B), and promote the activity of fatty acid synthetase [12, 13]. In turn, it was reported that dyslipidemia influenced HBV infection, which 
depended on the presence of cholesterol in the viral envelope [14-16]. Furthermore, an increased body mass index in CHB patients was found to be related to hepatic steatosis [15]. Cholesterol has been previously reported to promote HBV infection [16]. It has been previously shown that dyslipidemia is related to the therapeutic response of patients with chronic hepatitis $\mathrm{C}$ towards PEG-IFN $[17,18]$. LDL-cholesterol (LDL-C) is known to be a predictor of early and sustained virological response. Recent studies have shown that dyslipidemia affects the efficacy of IFN in patients with CHB [19]. However, very limited information is available regarding the effects of dyslipidemia on the efficacy of NAs in CHB patients. Thus, the present study aimed to retrospectively analyze the effects of dyslipidemia on the antiviral efficacy of NAs in HBeAg-positive CHB patients.

\section{Methods}

\section{Patient data}

The study selected a total of 179 newly treated CHB patients with HBeAg-positive hospitalization in the First Affiliated Hospital of Wenzhou Medical University from January 2010 to December 2013, who were diagnosed as per the guidelines for the prevention and treatment of chronic hepatitis B (2015) [20]. The study was approved by the Ethics Committee of the First Affiliated Hospital of the Wenzhou Medical University, and the informed consent of all patients was obtained.

Inclusion criteria: age $\geq 16$ years; serum $\mathrm{HBV}$ DNA level $\geq 20,000 \mathrm{IU} / \mathrm{mL} ; \mathrm{HBsAg}$ positive, duration $>6$ months; HBeAg-positive and anti-HBe-negative. Exclusive criteria: previously received antiviral, immunomodulatory drugs, or corticosteroid therapy; liver diseases by other causes, elevated ALT caused by non-liver diseases; HCV, HDV, or HIV infection; and decompensated liver diseases history or stage. According to the dyslipidemia complication, patients were categorized into two groups, including 68 subjects with dyslipidemia and 111 without dyslipidemia. The diagnostic criteria for dyslipidemia followed the Prevention Guidelines of Dyslipidemia in Chinese Adults (2016 Revision) [7]. The treatment regimens included oral lamivudine (Heptodin, GlaxoSmithKline Pharmaceutical Co., Ltd. Poznań, Poland) 100 mg qd combined with adefovir dipivoxil (Hepsera, GlaxoSmithKline Pharmaceutical Co., Ltd.) $10 \mathrm{mg}$ qd ( $n=$ 14); or telbivudine monotherapy $600 \mathrm{mg}$ qd (Sebivo, Beijing Novartis Pharmaceutical Co., Ltd., Beijing, China) $(n=78)$; or entecavir monotherapy (Baraclude, Sino-American Shanghai Squibb Pharmaceutical Co., Ltd., Shanghai, China) $0.5 \mathrm{mg}$ qd $(n=87)$; 5 -year of treatment. If the drug was discontinued or other drugs were used during the treatment period, the case was withdrawn from the study.

\section{Detection indicator}

Venous blood was drawn for various blood tests after fasting overnight for $12 \mathrm{~h}$. Lipid indexes, including TC $(2.44-5.17 \mathrm{mmol} / \mathrm{L}), \quad$ TG $(0.4-1.70 \mathrm{mmol} / \mathrm{L}), \quad$ LDL-C $(2.07-3.10 \mathrm{mmol} / \mathrm{L})$, HDL-C $(1.29-1.55 \mathrm{mmol} / \mathrm{L})$, and biochemical indexes including ALT (7-40 U/L), AST (13-35 U/L), ALP (50-135 U/L), and r-GT (7-45 U/L) were measured by using standard techniques. Semiquantitative analysis of HBV serological marker, including $\mathrm{HBsAg}$ and $\mathrm{HBeAg}$, was performed by electrochemiluminescence immunoassay (ECLIA). In addition, the quantitative detection of HBV DNA was performed, and the $\mathrm{HBeAg}$ seroconversion rates and the virological response rates from 1 to 5 years of treatment were calculated. $\mathrm{HBeAg}$ seroconversion was analyzed by detecting anti-HBE and HBeAg. The standard of virological response was the content of hepatitis B virus nucleic acid $<30 \mathrm{IU} / \mathrm{mL}$, as detected by $\mathrm{ABI} 7500$.

\section{Statistical analysis}

SPSS 25.0 statistical software was used for all data analyses. Measurement data are presented as mean \pm SD using $\tau$ tests. Enumeration data were assessed by the rate utilizing $x^{2}$ test, the corrected $x^{2}$ test, or Fisher's exact test. Correlation analysis was performed by using Binary Logistic Regression analysis. $P<0.05$ indicated statistical significance.

\section{Results}

\section{Baseline data}

The present study involved the assessment of data obtained from 179 HBeAg-positive $\mathrm{CHB}$ patients, which included 143 males and 36 females, aged 16-75 years (average age $=40.4 \pm 12.0$ years). These CHB patients were primarily subjected to treatment either with combination therapy involving lamivudine and adefovir dipivoxil, telbivudine monotherapy, or entecavir monotherapy, for 5 years. In particular, 14 subjects were treated with lamivudine combined with adefovir dipivoxil, 78 subjects were treated with telbivudine monotherapy, and 87 subjects were treated with entecavir monotherapy. Among 179 patients, 17 subjects exhibited hypercholesterolemia, 21 subjects had hypertriglyceridemia, and 30 subjects had mixed hyperlipidemia. As shown in Table 1, MBI, TC, TG, and LDL-C were found to be significantly higher in the patients belonging to the dyslipidemia group, when compared with those without dyslipidemia. However, no significant differences were recorded between the two groups in terms of age, gender, ALT, AST, HBsAg, HBeAg, HBV DNA, treatment regimens, or other indicators. 
Table 1 Comparison of baseline characteristics between dyslipidemia and normolipidemic groups

\begin{tabular}{|c|c|c|c|c|}
\hline Baseline Data & $\begin{array}{l}\text { Dyslipidemia Group } \\
68\end{array}$ & $\begin{array}{l}\text { Normolipidemic Group } \\
111\end{array}$ & $\begin{array}{l}\tau / \\
x^{2} \text { value }\end{array}$ & $P$ \\
\hline Male (n, \%) & 57 & 86 & 0.415 & 0.520 \\
\hline Age (years) & $39.5 \pm 11.9$ & $40.9 \pm 12.2$ & 0.795 & 0.428 \\
\hline Combined therapy (n, \%) & 5 & 9 & 0.187 & 0.911 \\
\hline $\mathrm{BMI}\left(\mathrm{kg} / \mathrm{m}^{2}\right)$ & $25.0 \pm 3.1$ & $22.4 \pm 2.2$ & 5.428 & $0.000^{*}$ \\
\hline WBC $\left(\times 10^{9} / \mathrm{L}\right)$ & $6.3 \pm 2.1$ & $5.6 \pm 1.4$ & 2.897 & $0.004^{*}$ \\
\hline NE\% & $0.6 \pm 0.1$ & $0.6 \pm 0.1$ & 0.138 & 0.890 \\
\hline $\operatorname{NE}\left(\times 10^{9} / L\right)$ & $3.7 \pm 1.7$ & $3.2 \pm 1.2$ & 2.586 & $0.011^{*}$ \\
\hline $\mathrm{RBC}\left(\times 10^{12} / \mathrm{L}\right)$ & $4.8 \pm 0.6$ & $4.8 \pm 0.5$ & 0.217 & 0.828 \\
\hline $\mathrm{HB}(\mathrm{g} / \mathrm{L})$ & $147.9 \pm 15.7$ & $145.5 \pm 14.9$ & 1.048 & 0.296 \\
\hline RDW (\%) & $13.4 \pm 1.2$ & $13.3 \pm 2.8$ & 0.158 & 0.875 \\
\hline $\operatorname{PLT}\left(\times 10^{9} / L\right)$ & $230.5 \pm 78.5$ & $215.2 \pm 60.9$ & 1.368 & 0.174 \\
\hline PT (s) & $13.5 \pm 0.8$ & $13.4 \pm 1$ & 0.715 & 0.476 \\
\hline PTA (\%) & $92.2 \pm 10.0$ & $92.8 \pm 13.3$ & 0.341 & 0.733 \\
\hline INR & $1 \pm 0.1$ & $1 \pm 0.1$ & 0.180 & 0.857 \\
\hline$F(g / L)$ & $3.1 \pm 0.6$ & $3.1 \pm 0.9$ & 0.398 & 0.691 \\
\hline APTT (s) & $37.3 \pm 4.2$ & $36.8 \pm 5.2$ & 0.795 & 0.428 \\
\hline APTTR & $1.0 \pm 0.1$ & $1.0 \pm 0.2$ & 0.140 & 0.889 \\
\hline$\Pi(\mathrm{s})$ & $17.1 \pm 1.3$ & $17.1 \pm 1.5$ & 0.175 & 0.862 \\
\hline$T T R$ & $1.0 \pm 0.1$ & $1.0 \pm 0.1$ & 0.228 & 0.820 \\
\hline TB (umol/L) & $25.4 \pm 58.9$ & $15.1 \pm 20.1$ & 1.692 & 0.092 \\
\hline DBIL (umol/L) & $15.3 \pm 50.3$ & $7.1 \pm 18.1$ & 1.502 & 0.135 \\
\hline TP $(g / L)$ & $75.5 \pm 6.2$ & $73.7 \pm 6.6$ & 1.889 & 0.061 \\
\hline$A(g / L)$ & $43.9 \pm 5.6$ & $44.4 \pm 5.3$ & 0.587 & 0.558 \\
\hline ALT (U/L) & $349.1 \pm 275.2$ & $297.1 \pm 224$ & 1.314 & 0.191 \\
\hline AST (U/L) & $249.1 \pm 175$ & $266.7 \pm 175.9$ & 0.830 & 0.408 \\
\hline ALP $(U / L)$ & $90 \pm 22$ & $84.1 \pm 23.2$ & 1.719 & 0.088 \\
\hline r-GT (U/L) & $75.9 \pm 56.6$ & $72.5 \pm 42$ & 0.430 & 0.688 \\
\hline $\mathrm{FBG}(\mathrm{mmol} / \mathrm{L})$ & $5.3 \pm 1.3$ & $5.4 \pm 1.6$ & 0.697 & 0.487 \\
\hline BUN (mmol/L) & $4.8 \pm 1.4$ & $4.5 \pm 1.1$ & 1.338 & 0.184 \\
\hline $\mathrm{CR}(\mathrm{mmol} / \mathrm{L})$ & $69.3 \pm 12.5$ & $67.6 \pm 13.7$ & 0.838 & 0.403 \\
\hline UA (umol/L) & $379.9 \pm 105$ & $359.9 \pm 99.4$ & 1.257 & 0.211 \\
\hline $\mathrm{TC}(\mathrm{mmol} / \mathrm{L})$ & $5.5 \pm 1.3$ & $4.0 \pm 0.7$ & 10.210 & $0.000^{*}$ \\
\hline $\mathrm{TG}(\mathrm{mmol} / \mathrm{L})$ & $2.2 \pm 0.8$ & $1.1 \pm 0.3$ & 12.633 & $0.000^{*}$ \\
\hline $\mathrm{HDL}-\mathrm{C}(\mathrm{mmol} / \mathrm{L})$ & $1.1 \pm 0.4$ & $1.1 \pm 0.3$ & 0.284 & 0.777 \\
\hline $\mathrm{LDL}-\mathrm{C}(\mathrm{mmol} / \mathrm{L})$ & $3.4 \pm 1.0$ & $2.3 \pm 0.7$ & 8.574 & $0.000^{*}$ \\
\hline $\mathrm{HBsAg} \mathrm{S} / \mathrm{CO}$ & $7557.4 \pm 10,826.3$ & $5377.3 \pm 7487.7$ & 1.494 & 0.137 \\
\hline $\mathrm{HBeAg} \mathrm{S} / \mathrm{CO}$ & $901.5 \pm 514.4$ & $777.3 \pm 512.9$ & 1.567 & 0.119 \\
\hline HBV DNA $\log _{10} \mid \mathrm{U} / \mathrm{mL}$ & $7.4 \pm 1.2$ & $7.6 \pm 1.1$ & 1.114 & 0.267 \\
\hline
\end{tabular}

${ }^{*}$ comparison between the dyslipidemia and normolipidemic groups $P<0.05$

HBeAg seroconversion rates after antiviral treatment with NAs

As shown in Table 2, seroconversion rates for the $\mathrm{HBeAg}$ group with dyslipidemia were recorded to be
$10.3,13.2,17.6$, and $22.1 \%$ for years $1,2,3$, and 4 , respectively. These values were found to be lower than those reported for normolipidemic group (11.7, 16.2, 18.0 , and $33.3 \%$, respectively), however, these differences 
Table 2 Comparison of the HBeAg serological conversion rates between the dyslipidemia and normolipidemic groups at different treatment times (number of subjects, \%)

\begin{tabular}{|c|c|c|c|c|c|c|}
\hline \multirow[t]{2}{*}{ Groups } & \multirow{2}{*}{$\begin{array}{l}\text { Number } \\
\text { of } \\
\text { Subjects }\end{array}$} & \multicolumn{5}{|c|}{ HBeAg Serological Conversion Rate } \\
\hline & & 1st year & 2nd year & 3rd year & 4th year & 5th year \\
\hline Dyslipidemia Group & 68 & $7(10.3)$ & $9(13.2)$ & $12(17.6)$ & $15(22.1)$ & $19(27.9)$ \\
\hline Normolipidemic Group & 111 & $13(11.7)$ & $18(16.2)$ & $20(18.0)$ & $37(33.3)$ & $48(43.2)$ \\
\hline Test value & & 0.085 & 0.293 & 0.004 & 2.601 & 4.216 \\
\hline$P$ & & 0.770 & 0.589 & 0.950 & 0.107 & $0.040^{*}$ \\
\hline
\end{tabular}

*comparison between the dyslipidemia and normolipidemic groups $P<0.05$

were not statistically significant $\left(\chi^{2}=0.085,0.293,0.004\right.$, and 2.601, respectively, $P>0.05)$. For the 5 th year, HBeAg seroconversion rates of 27.9 and $43.2 \%$ were recorded for the dyslipidemia group and normolipidemic group, respectively. Importantly, these differences were found to be statistically significant $\left(X^{2}=4.216, P<0.05\right)$ (Fig. 1).

\section{Virological response rates for NAs after antiviral treatment}

The virological response rates for HBV DNA in dyslipidemia group were recorded to be 63.2, 69.1, 76.5, 83.8, and $89.7 \%$ for years $1,2,3,4$, and 5 , respectively. These values were lower than the corresponding values for normolipidemic group (69.4, 74.8, 83.8, 92.8, and 95.5\%, respectively). However, these differences were not statistically significant $\left(\chi^{2}=0.718,0.679,1.466,3.573\right.$, and 1.429, respectively, $P>0.05$ ) (Table 3 , Fig. 2).

\section{Comparison of baseline data, virological response, and HBeAg seroconversion}

Among 179 subjects, 14 were treated with lamivudine combined with adefovir dipivoxil, 78 were treated with telbivudine monotherapy, while 87 were treated with entecavir. No differences were reported among these three groups in terms of ALT, AST, HBsAg, HBeAg, or HBV-DNA. In addition to these, no significant differences were recorded for HBV DNA virological response

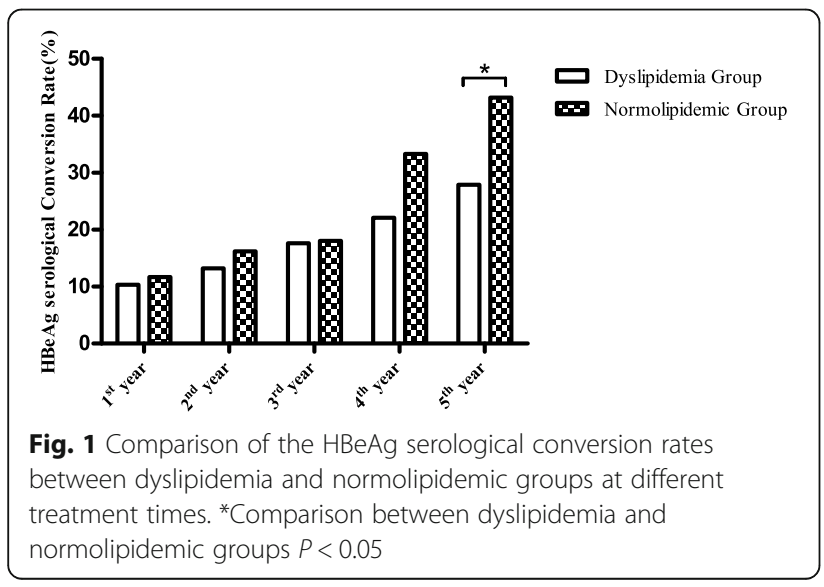

rates and $\mathrm{HBeAg}$ negative rates for these three groups (Table 4, Figs. 3 and 4).

\section{Correlation analysis between dyslipidemia and $\mathrm{HBeAg}$ seroconversion}

The results for single-factor logistic regression analysis reported significant differences between groups with and without seroconversion, particularly in terms of group, gender, PTA, ALT, AST, CR, and LDL-C (OR = 1.965, $2.212,0.959,1.003,1.004,0.97$, and 0.668 , respectively; $P=0.041,0.036,0.004,0.000,0.014$, and 0.022 , respectively, Table 5). The factors influencing HBeAg seroconversion were included in multivariate logistic regression analysis, and the results suggested that dyslipidemia and male gender acted as risk factors for HBeAg seroconversion $(\mathrm{OR}=1.993$ and 2.317; $P=0.038$ and 0.029, respectively).

\section{Discussion}

Chronic HBV infection is one of the major health concerns worldwide, with global infection rates of $3.6 \%$. Among these CHB infected patients, 250-350 million people are positive for HBsAg, which varies according to geographical location [21, 22]. When chronic viral infections are left undiagnosed or untreated, it leads to lifethreatening complications such as liver cirrhosis and hepatocellular carcinoma (HCC). Importantly, the availability of a prophylactic vaccine has reduced the emergence of new HBV infections among children aged $<5$ years, who are most vulnerable to the development of persistent infections [23]. So far, two therapeutic strategies have been approved for the management of chronic HBV infection, namely nucleoside/nucleotide analogs (NAs) and interferon $\alpha$ (IFN- $\alpha) /$ polyethylene glycol interferon (PEG-IFN) [24].

Over the last three decades, China has witnessed a considerable increase in the prevalence rates of dyslipidemia, which corresponded to the development of the national economy of China [7]. Dyslipidemia is directly related to poor eating habits, lack of exercise, and increased age, and it often leads to chronic kidney diseases, cardiovascular disease, diabetes, fatty liver, and other diseases. Blood lipid metabolism has been 
Table 3 Comparison of HBV DNA virological response rates between the dyslipidemia and normolipidemic groups at different treatment times (number of subjects, \%)

\begin{tabular}{|c|c|c|c|c|c|c|}
\hline \multirow[t]{2}{*}{ Groups } & \multirow{2}{*}{$\begin{array}{l}\text { Number } \\
\text { of } \\
\text { Subjects }\end{array}$} & \multicolumn{5}{|c|}{ HBV DNA Virological Response Rate } \\
\hline & & 1st year & 2nd year & 3rd year & 4th year & 5th year \\
\hline Dyslipidemia Group & 68 & $43(63.2)$ & $47(69.1)$ & $52(76.5)$ & $57(83.8)$ & $61(89.7)$ \\
\hline Normolipidemic Group & 111 & $77(69.4)$ & $83(74.8)$ & $93(83.3)$ & $103(92.8)$ & $106(95.5$ \\
\hline Test value & & 0.718 & 0.679 & 1.466 & 3.575 & 1.429 \\
\hline$P$ & & 0.397 & 0.410 & 0.226 & 0.059 & 0.232 \\
\hline
\end{tabular}

previously shown to be influenced by chronic HBV infection [8-10], which in turn influences HBV infection [14-16]. Recent studies suggested that dyslipidemia was related to PEG IFN- $\alpha$ responses in CHB patients [19]. However, limited studies have explored the effects of dyslipidemia on the efficacy of NAs in $\mathrm{CHB}$ patients. Therefore, clinical investigations are required to assess the impact of dyslipidemia on the antiviral efficacy of NAs on CHB patients. Consequently, the present study explored the effects of dyslipidemia on the antiviral efficacy of NAs on HBeAg-positive CHB patients. Current treatment guidelines recommend the administration of PEG IFN- $\alpha$, entecavir, or tenofovir disoproxil as the first choice of treatment for primary patients. However, in some of the patients, the use of telbivudine monotherapy or lamivudine combined with adefovir dipivoxil is maintained as antiviral therapy.

The results of the present study showed that virological response and $\mathrm{HBeAg}$ seroconversion rates were lower in the group with dyslipidemia when compared with the subjects included in the normolipidemic group. Specifically, no significant differences were recorded in virological response rates for each time point during the treatment. In addition to this, no statistically significant differences were observed in HBeAg seroconversion rates during the first 4 years of the treatment. For the 5 th year, statistically, significant differences were recorded for $\mathrm{HBeAg}$ seroconversion rates for the two groups. HBeAg seroconversion is usually associated with

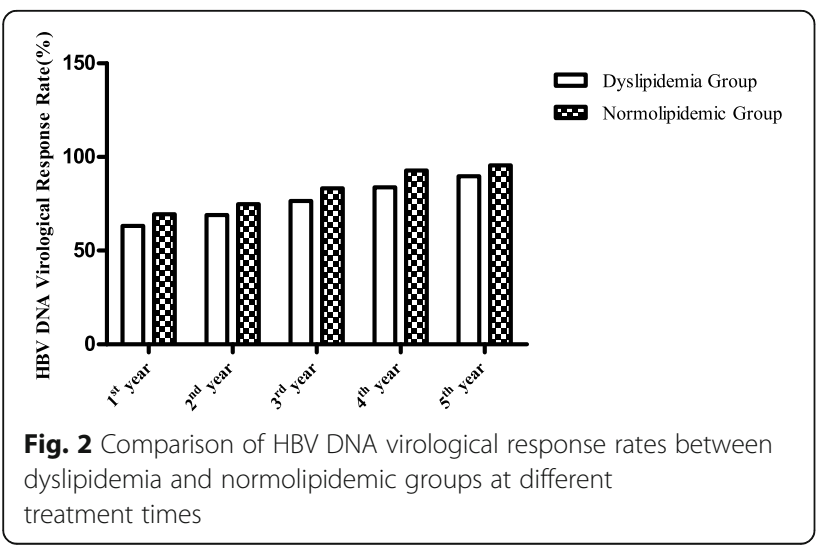

progressive reduction of the viral DNA quantification. Thus, it was surprising that HBV DNA was not associated with dyslipidemia status. This might be attributed to association with only late-HBeAg seroconversion. The results for binary logistic regression analysis showed that dyslipidemia and male gender acted as risk factors for HBeAg seroconversion. Dyslipidemia is known to affect human immune function, however, the underlying mechanism for the same remains unknown. Bile acid was previously reported to promote the expression of HBV and weaken the antiviral effects of IFN [25]. Since bile acid originates from cholesterol, it can be proposed that bile acid metabolism in CHB patients is affected by dyslipidemia, which influences antiviral effects. Additionally, metabolic stress caused by dyslipidemia has been shown to induce harmful immune activation, resulting in high levels of $\mathrm{CD} 4+\mathrm{T}$ cells and lowered $\mathrm{HBeAg}$ seroconversion, most probably as a consequence of cellular dysfunction [26, 27].

\section{Comparisons with other studies and what does the current work add to the existing knowledge}

Until date, several studies have been conducted to evaluate the effects of dyslipidemia on infection and treatment of hepatitis B. In terms of novelty, in the present study, the effects of dyslipidemia on the E-antigen seroconversion rate of patients with hepatitis B treated by nucleoside (acid) analogues have been discussed for the first time. As a supplement to the existing knowledge, the present study confirmed that dyslipidemia is an independent risk factor for the reduction of seroconversion rates of $\mathrm{HBeAg}$ in patients with hepatitis $\mathrm{B}$ treated by NAs.

\section{Study strength and limitations}

This study has several strengths. First, the participants were involved in a long-term follow-up, as a result, this study has high homogeneity and obtained systematic and continuous data. Second, this study provides reference for the clinical treatment of hepatitis $B$ patients with dyslipidemia. However, the present study is associated with certain limitations. The present study was based on retrospective analysis and requires 
Table 4 Baseline data and comparison of the virological response rates and HBeAg serological conversion after different treatment regimens

\begin{tabular}{|c|c|c|c|c|c|}
\hline Parameters & $\begin{array}{l}\text { Combined therapy } \\
14\end{array}$ & $\begin{array}{l}\text { Entecavir } \\
87\end{array}$ & $\begin{array}{l}\text { Telbivudine } \\
78\end{array}$ & $\begin{array}{l}\text { Test } \\
\text { Value }\end{array}$ & $p$ \\
\hline Dyslipidemia (n, \%) & $5(35.7)$ & $32(36.8)$ & 31 (39.7) & 0.185 & 0.911 \\
\hline Male (n, \%) & $12(85.7)$ & $73(83.9)$ & $58(74.4)$ & 2.640 & 0.267 \\
\hline Age (year) & $46.3 \pm 11.7$ & 39. \pm 10.1 & $40.4 \pm 13.8$ & 2.007 & 0.138 \\
\hline $\mathrm{BMI}\left(\mathrm{kg} / \mathrm{m}^{2}\right)$ & $23.9 \pm 4.8$ & $23.4 \pm 2.8$ & $23.4 \pm 2.5$ & 0.234 & 0.792 \\
\hline WBC $\left(\times 10^{9} / \mathrm{L}\right)$ & $5.6 \pm 1.7$ & $5.8 \pm 1.8$ & $6.0 \pm 1.8$ & 0.487 & 0.615 \\
\hline NE\% & $0.6 \pm 0.1$ & $0.6 \pm 0.1$ & $0.6 \pm 0.0$ & 0.330 & 0.720 \\
\hline $\mathrm{NE}\left(\times 10^{9} / \mathrm{L}\right)$ & $3.4 \pm 1.4$ & $3.3 \pm 1.4$ & $3.5 \pm 1.4$ & 0.230 & 0.795 \\
\hline $\mathrm{RBC}\left(\times 10^{12} / \mathrm{L}\right)$ & $4.8 \pm 0.4$ & $4.8 \pm 0.5$ & $4.8 \pm 0.6$ & 0.248 & 0.780 \\
\hline $\mathrm{HB}(\mathrm{g} / \mathrm{L})$ & $142.1 \pm 16.3$ & $146.1 \pm 13.6$ & $147.5 \pm 16.7$ & 0.781 & 0.460 \\
\hline RDW (\%) & $13.8 \pm 2.1$ & $13.6 \pm 3.1$ & $13.0 \pm 0.9$ & 1.757 & 0.176 \\
\hline $\operatorname{PLT}\left(\times 10^{9} / \mathrm{L}\right)$ & $221.6 \pm 97.1$ & $216.2 \pm 68.3$ & $226.3 \pm 62.6$ & 0.444 & 0.642 \\
\hline PT (s) & $14.0 \pm 1.8$ & $13.4 \pm 0.9$ & $13.4 \pm 1.0$ & 2.418 & 0.092 \\
\hline PTA (\%) & $89.1 \pm 22.2$ & $93.1 \pm 12.1$ & $92.6 \pm 9.6$ & 0.637 & 0.530 \\
\hline INR & $1.1 \pm 0.3$ & $1.0 \pm 0.1$ & $1.0 \pm 0.1$ & 3.547 & 0.031 \\
\hline$F(g / L)$ & $3.2 \pm 1.15$ & $3.1 \pm 0.8$ & $3.0 \pm 0.8$ & 0.373 & 0.689 \\
\hline $\mathrm{APTT}(\mathrm{s})$ & $37.5 \pm 6.4$ & $37.3 \pm 4.2$ & $36.6 \pm 5.1$ & 0.498 & 0.609 \\
\hline APTTR & $1.1 \pm 0.3$ & $1.0 \pm 0.1$ & $1.0 \pm 0.1$ & 1.309 & 0.273 \\
\hline$\pi(s)$ & $16.8 \pm 1.8$ & $17.2 \pm 1.4$ & $17.1 \pm 1.4$ & 0.477 & 0.621 \\
\hline TTR & $1.0 \pm 0.2$ & $1.0 \pm 0.1$ & $1.0 \pm 0.1$ & 0.059 & 0.943 \\
\hline TB (umol/L) & $58.6 \pm 131.3$ & $16.2 \pm 15.6$ & $15.1 \pm 12.8$ & 1.530 & 0.465 \\
\hline DBIL (umol/L) & $46.1 \pm 113.55$ & $7.9 \pm 11.8$ & $6.9 \pm 11.0$ & 0.841 & 0.657 \\
\hline TP $(g / L)$ & $70.9 \pm 8.2$ & $74.6 \pm 6.63$ & $74.7 \pm 5.9$ & 2.263 & 0.107 \\
\hline$A(g / L)$ & $42.7 \pm 7.1$ & $44.3 \pm 5.6$ & $44.4 \pm 4.9$ & 0.621 & 0.539 \\
\hline $\operatorname{ALT}(\mathrm{U} / \mathrm{L})$ & $247.4 \pm 205.0$ & $346.9 \pm 287.6$ & $295.8 \pm 193.0$ & 1.509 & 0.224 \\
\hline AST (U/L) & $228.6 \pm 130.2$ & $248.1 \pm 192.7$ & $221.9 \pm 162.4$ & 0.467 & 0.627 \\
\hline $\mathrm{ALP}(\mathrm{U} / \mathrm{L})$ & $81.4 \pm 26.6$ & $88.3 \pm 21.8$ & $85.0 \pm 23.5$ & 0.805 & 0.449 \\
\hline R-GT (U/L) & $56.6 \pm 37.9$ & $78.8 \pm 56.6$ & $71.4 \pm 37.4$ & 1.492 & 0.228 \\
\hline FBG (mmol/L) & $6.2 \pm 2.4$ & $5.4 \pm 1.4$ & $5.3 \pm 1.3$ & 2.699 & 0.070 \\
\hline BUN (mmol/L) & $4.4 \pm 1.5$ & $4.7 \pm 1.3$ & $4.6 \pm 1.1$ & 0.358 & 0.699 \\
\hline $\mathrm{CR}(\mathrm{mmol} / \mathrm{L})$ & $62.4 \pm 15.9$ & $69.2 \pm 11.2$ & $68.3 \pm 14.6$ & 1.629 & 0.199 \\
\hline UA (umol/L) & $330.7 \pm 143.1$ & $364.4 \pm 98.5$ & $377.8 \pm 96.2$ & 1.358 & 0.260 \\
\hline $\mathrm{TC}(\mathrm{mmol} / \mathrm{L})$ & $4.0 \pm 1.4$ & $4.6 \pm 1.1$ & $4.6 \pm 1.2$ & 1.826 & 0.164 \\
\hline TG $(\mathrm{mmol} / \mathrm{L})$ & $1.5 \pm 0.7$ & $1.5 \pm 0.7$ & $1.5 \pm 0.8$ & 0.215 & 0.807 \\
\hline $\mathrm{HDL}-\mathrm{C}(\mathrm{mmol} / \mathrm{L})$ & $0.9 \pm 0.3$ & $1.1 \pm 0.3$ & $1.1 \pm 0.3$ & 4.091 & $0.018^{*}$ \\
\hline LDL-C (mmol/L) & $2.3 \pm 1.1$ & $2.7 \pm 0.9$ & $2.8 \pm 1.0$ & 1.759 & 0.175 \\
\hline $\mathrm{HBsAg}(\mathrm{S} / \mathrm{CO})$ & $8269.4 \pm 13,647.8$ & $5988.1 \pm 9224.3$ & $5921.1 \pm 7409.6$ & 0.434 & 0.649 \\
\hline $\mathrm{HBeAg}(\mathrm{S} / \mathrm{CO})$ & $944.3 \pm 549.4$ & $798.9 \pm 455.3$ & $832.3 \pm 573.9$ & 0.491 & 0.613 \\
\hline HBVDNA $\log _{10} \mathrm{IU} / \mathrm{mL}$ & $7.9 \pm 0.8$ & $7.5 \pm 1.2$ & $7.5 \pm 1.1$ & 0.625 & 0.537 \\
\hline \multicolumn{6}{|l|}{ The first year } \\
\hline HBV DNA Virological Response Rate & $9(64.3)$ & $59(67.8)$ & $52(66.7)$ & 0.076 & 0.963 \\
\hline HBeAg serological Conversion Rate & $2(14.3)$ & $13(14.9)$ & $5(6.4)$ & 3.147 & 0.207 \\
\hline
\end{tabular}

The second-year 
Table 4 Baseline data and comparison of the virological response rates and HBeAg serological conversion after different treatment regimens (Continued)

\begin{tabular}{|c|c|c|c|c|c|}
\hline \multirow[t]{2}{*}{ Parameters } & \multirow{2}{*}{$\begin{array}{l}\text { Combined therapy } \\
14\end{array}$} & \multirow{2}{*}{$\begin{array}{l}\text { Entecavir } \\
87\end{array}$} & \multirow{2}{*}{$\begin{array}{l}\text { Telbivudine } \\
78\end{array}$} & \multirow{2}{*}{$\begin{array}{l}\text { Test } \\
\text { Value }\end{array}$} & \multirow[t]{2}{*}{$p$} \\
\hline & & & & & \\
\hline HBV DNA Virological Response Rate & $11(78.6)$ & $63(72.4)$ & $56(71.8)$ & 0.276 & 0.871 \\
\hline HBeAg serological Conversion Rate & $2(14.3)$ & $13(14.9)$ & $12(15.4)$ & 0.014 & 0.993 \\
\hline \multicolumn{6}{|l|}{ The third-year } \\
\hline HBV DNA Virological Response Rate & $11(78.6)$ & $72(82.8)$ & $62(79.5)$ & 0.343 & 0.843 \\
\hline HBeAg serological Conversion Rate & $2(14.3)$ & $15(17.2)$ & $15(19.2)$ & 0.243 & 0.886 \\
\hline \multicolumn{6}{|l|}{ The fourth-year } \\
\hline HBV DNA Virological Response Rate & $11(78.6)$ & $78(89.7)$ & $71(91)$ & 1.943 & 0.379 \\
\hline HBeAg serological Conversion Rate & $3(21.4)$ & $22(25.3)$ & $27(34.6)$ & 2.152 & 0.341 \\
\hline \multicolumn{6}{|l|}{ The fifth-year } \\
\hline HBV DNA Virological Response Rate & $13(92.9)$ & $82(94.3)$ & $72(92.3)$ & 0.252 & 0.882 \\
\hline HBeAg serological Conversion Rate & $4(28.6)$ & $29(33.3)$ & $34(43.6)$ & 2.343 & 0.310 \\
\hline
\end{tabular}

*variance analysis or nonparametric test in different treatment regimens $P<0.05$

confirmation via clinical prospective studies. Furthermore, the present study assessed only a small number of subjects due to the long follow-up period, potentially introducing study bias.

\section{Conclusions}

Altogether the findings of the present study demonstrated that dyslipidemia influenced HBeAg seroconversion. As such, HBeAg seroconversion rates could be improved by controlling blood lipid levels. Consequently, in the case of $\mathrm{CHB}$ patients with dyslipidemia, blood lipid levels should be controlled during antiviral therapy. This could be possibly achieved by including diet regulation, weight management, and temperance. If required, anti-hyperlipidemic drugs might be applied to control lipid levels in the blood. However, liver functions should be monitored in such cases as some of the antihyperlipidemic drugs have been shown to exert adverse effects on liver functions. In case of adverse reactions, anti-hyperlipidemic drugs must be stopped. The results for $\mathrm{HBeAg}$ seroconversion indicated that the virus was in the low replication stage, and the liver damage was mitigated. Therefore, dyslipidemia was found to be related to the progression of liver damage. These findings suggested that the HBeAg conversion rate could be improved by controlling the blood lipid levels, which could further mitigate liver damage.

Different types of dyslipidemia might lead to different situations. Since bile acid is known to upregulate the expression of HBV genes [25] and cholesterol has been shown to affect the metabolism of bile acid, abnormalities in total cholesterol levels could play a key role in the process of dyslipidemia and thus influence $\mathrm{HBeAg}$ seroconversion. Future studies must involve more samples, and the correlation of different types of dyslipidemia with $\mathrm{HBeAg}$ seroconversion should be explored. In addition to this, the effects of reduction of blood lipid levels on $\mathrm{HBeAg}$ conversion rate in
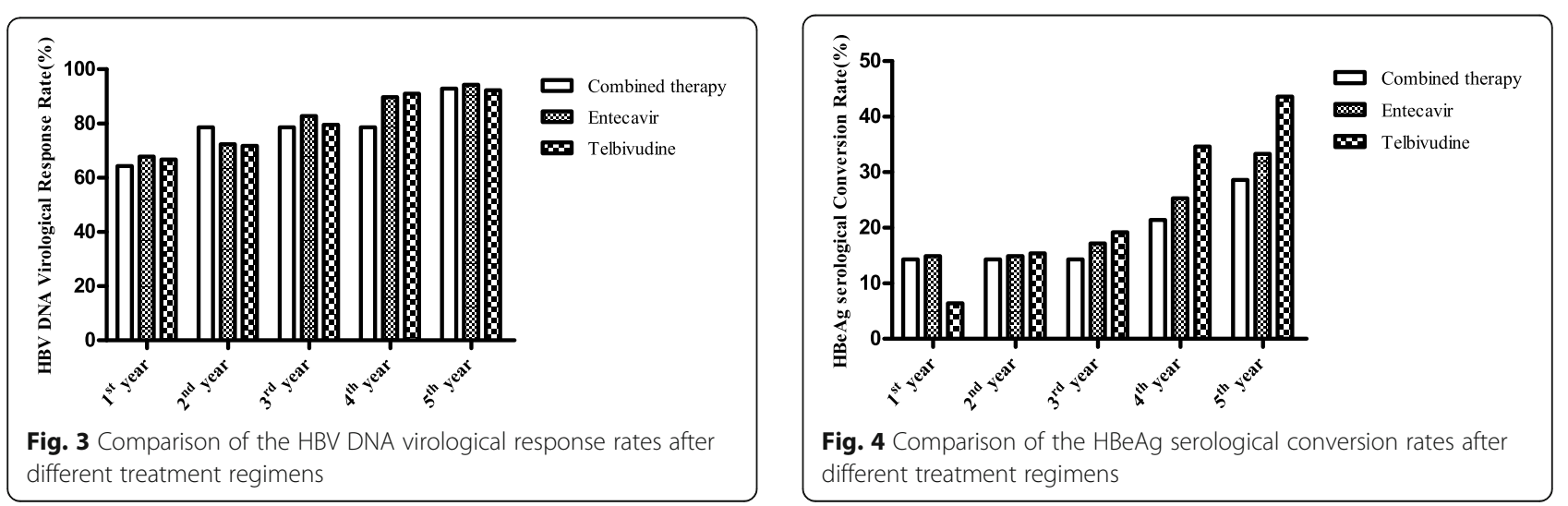
Table 5 Single-factor logistic analyses

\begin{tabular}{|c|c|c|}
\hline Baseline data & $P$ & OR $(95 \% \mathrm{Cl})$ \\
\hline group & $0.041^{*}$ & $1.965(1.026-3.761)$ \\
\hline Male (n, \%) & $0.036^{*}$ & $2.212(1.005-4.639)$ \\
\hline Age (years) & 0.079 & $0.977(0.952-1.003)$ \\
\hline Combined therapy $(\mathrm{n}, \%)$ & 0.177 & $0.647(0.344-1.271)$ \\
\hline $\mathrm{BMI}\left(\mathrm{kg} / \mathrm{m}^{2}\right)$ & 0.272 & $0.937(0.834-1.052)$ \\
\hline WBC $\left(\times 10^{9} / L\right)$ & 0.352 & 0.919 (0.770-1.098) \\
\hline NE\% & 0.285 & $0.189(0.009-3.999)$ \\
\hline $\mathrm{NE}\left(\times 10^{9} / \mathrm{L}\right)$ & 0.157 & $0.846(0.671-1.067)$ \\
\hline $\operatorname{RBC}\left(\times 10^{12} / \mathrm{L}\right)$ & 0.671 & $0.886(0.508-1.547)$ \\
\hline $\mathrm{HB}(\mathrm{g} / \mathrm{L})$ & 0.603 & $1.005(0.985-1.026)$ \\
\hline RDW (\%) & 0.240 & $0.837(0.622-1.126)$ \\
\hline $\operatorname{PLT}\left(\times 10^{9} / \mathrm{L}\right)$ & 0.955 & $1.000(0.955-1.004)$ \\
\hline $\mathrm{PT}(\mathrm{s})$ & 0.065 & $1.362(0.981-1.890)$ \\
\hline PTA (\%) & $0.004^{*}$ & $0.959(0.932-0.987)$ \\
\hline INR & 0.732 & $1.505(0.145-15.615)$ \\
\hline$F(g / L)$ & 0.643 & $0.918(0.638-1.321)$ \\
\hline APTT (s) & 0.546 & $1.020(0.957-1.086)$ \\
\hline APTTR & 0.216 & $3.879(0.452-33.267)$ \\
\hline$\Pi \mathrm{T}(\mathrm{s})$ & 0.648 & $1.051(0.848-1.303)$ \\
\hline TTR & 0.694 & $1.925(0.074-50.085)$ \\
\hline TB (umol/L) & 0.873 & $0.999(0.991-1.007)$ \\
\hline DBIL (umol/L) & 0.891 & $0.999(0.990-1.009)$ \\
\hline $\mathrm{TP}(\mathrm{g} / \mathrm{L})$ & 0.450 & $0.982(0.937-1.029)$ \\
\hline$A(g / L)$ & 0.370 & $0.975(0.920-1.031)$ \\
\hline $\operatorname{ALT}(\mathrm{U} / \mathrm{L})$ & $0.000^{*}$ & $1.003(1.002-1.003)$ \\
\hline AST (U/L) & $0.000^{*}$ & $1.004(1.002-1.006)$ \\
\hline $\mathrm{ALP}(\mathrm{U} / \mathrm{L})$ & 0.507 & $1.004(0.991-1.018)$ \\
\hline $\mathrm{r}-\mathrm{GT}(\mathrm{U} / \mathrm{L})$ & 0.135 & $1.005(0.998-1.011)$ \\
\hline FBG $(\mathrm{mmol} / \mathrm{L})$ & 0.896 & $0.986(0.801-1.214)$ \\
\hline BUN (mmol/L) & 0.441 & $0.904(0.700-1.168)$ \\
\hline $\mathrm{CR}(\mathrm{mmol} / \mathrm{L})$ & $0.014^{*}$ & $0.970(0.946-0.994)$ \\
\hline UA (umol/L) & 0.635 & $1.001(0.998-1.004)$ \\
\hline TC $(\mathrm{mmol} / \mathrm{L})$ & 0.088 & $0.790(0.602-1.036)$ \\
\hline $\mathrm{TG}(\mathrm{mmol} / \mathrm{L})$ & 0.250 & $0.780(0.511-1.191)$ \\
\hline $\mathrm{HDL}-\mathrm{C}(\mathrm{mmol} / \mathrm{L})$ & 0.769 & $1.161(0.428-3.153)$ \\
\hline LDL-C (mmol/L) & $0.022^{*}$ & $0.668(0.473-0.944)$ \\
\hline $\mathrm{HBsAg} \mathrm{S/CO}$ & 0.979 & $1.000(1.000-1.000)$ \\
\hline $\mathrm{HBeAg} \mathrm{S/CO}$ & 0.945 & $1.000(0.999-1.001)$ \\
\hline HBV DNA $\log _{10} \mathrm{IU} / \mathrm{mL}$ & 0.061 & $0.774(0.592-1.012)$ \\
\hline
\end{tabular}

*single-factor logistic regression $P<0.05$

patients with dyslipidemia should be clarified. The control of blood lipid levels is of great significance for $\mathrm{CHB}$ patients as it can enhance $\mathrm{HBeAg}$ seroconversion rate and mitigate liver damage.

\section{Abbreviations}

ADV: Adefovir dipivoxil; Apo-B: Apolipoprotein B; cccDNA: Covalently closed circular DNA; CHB: Chronic hepatitis B; ECLIA: Electrochemiluminescence immunoassay; ETV: Entecavir; HBeAg: Hepatitis B e antigen; HBV: Hepatitis B virus; HCC: Hepatocellular carcinoma; HCV: Hepatitis C virus; HDL-C: High density lipoprotein cholesterol; IFNs: Interferon; LAM: Lamivudine; LdT: Telbivudine; NAs: Nucleoside (acid) analogues; Peg IFN-a: PEGylated interferon-alpha; TC: Cholesterol; TG: Triglyceride

\section{Acknowledgements}

Authors thank patients for their participation in the study.

\section{Authors' contributions}

Z.X.J.W.,X.S.: Conceptualisation; Z.X.,E.Z.: Methodology; J.Z.,L.Z.: Formal Analysis; Z.X.Z.Z.: Writing - Original Draft Preparation; J.W.,X.S.: Writing Review and Editing. The author(s) read and approved the final manuscript.

\section{Funding}

This study was supported by the Science and Technology Bureau of Jiaxing (Nos. 2018 AD32078), (Nos.2018AY32011) and Wenzhou (Nos.Y20190115).

\section{Availability of data and materials}

The datasets generated and/or analysed during the current study are not publicly available due [REASON WHY DATA ARE NOT PUBLIC] but are available from the corresponding author on reasonable request.

\section{Declarations}

Ethics approval and consent to participate

The study was approved by the Ethics Committee of the First Affiliated Hospital of Wenzhou Medical University, and the informed consent of all patients was obtained.

\section{Consent for publication}

Not applicable.

\section{Competing interests}

The authors declare that there are no conflicts of interest.

\section{Author details}

'Department of Gastroenterology, Wenzhou People's Hospital, Wenzhou 325000, China. ${ }^{2}$ Department of Gastroenterology, The First Affiliated Hospital of Wenzhou Medical University, Wenzhou 325000, China. ${ }^{3}$ Department of Infectious Diseases, The First Affiliated Hospital of Jiaxing College, Jiaxing 314000, China. ${ }^{4}$ Department of Infectious Diseases, The First Hospital of Jiaxing, Jiaxing 314000, China.

Received: 27 August 2021 Accepted: 18 October 2021

Published online: 30 October 2021

\section{References}

1. Lucifora J, Xia Y, Reisinger F, Zhang K, Stadler D, Cheng X, et al. Specific and nonhepatotoxic degradation of nuclea5 hepatitis B virus cccDNA. Science. 2014;343:1221-8. https://doi.org/10.1126/science.1243462.

2. WHO. WHO fact sheet. 2021. http://www.who.int/mediacentre/factsheets/fs2 04/en/. Accessed 20 July 2021.

3. Liu F, Zhuang H. Management of hepatitis B in China. Chin Med J. 2009;122: 3-4.

4. Funk ML, Rosenberg DM, Lok AS. World-wide epidemiology of HBeAgnegative chronic hepatitis $B$ and associated precore and core promoter variants. J Viral Hepat. 2002;9(1):52-61. https://doi.org/10.1046/j.1365-2893.2 002.00304.x

5. Lok AS, McMahon BJ, Brown RS Jr, Wong JB, Ahmed AT, et al. Antiviral therapy for chronic hepatitis B viral infection in adults: a systematic review and meta-analysis. Hepatology. 2016;63:284-306. https://doi.org/10.1002/ hep.28280.

6. Liaw YF, Chu CM. Hepatitis B virus infection. Lancet. 2009;373:582-92. https://doi.org/10.1016/S0140-6736(09)60207-5.

7. Zhu JR, Gao RL, Zhao SP, Lu GP, Zhao D. The guidelines for prevention and treatment of dyslipidemia in Chinese adults (revised edition 2016). Chin Circulation J. 2016:31:937-53. 
8. Shi YX, Huang CJ, Yang ZG. Impact of hepatitis B virus infection on hepatic metabolic signaling pathway. World I Ggastroenterol. 2016;22:8161-7. https://doi.org/10.3748/wjg.v22.i36.8161.

9. Yang $F$, Yan $S, H e ~ Y$, Wang F, Song $S$, Guo $Y$, et al. Expression of hepatitis $B$ virus proteins in transgenic mice alters lipid metabolism and induces oxidative stress in the liver. J Hepatol. 2008;48:12-9. https://doi.org/10.1016/ j.jhep.2007.06.021.

10. Wang $Y$, Wu T, Hu D, Weng $X$, Wang $X$, Chen $P$, et al. Intracellular hepatitis $B$ virus increases hepatic cholesterol deposition in alcoholic fatty liver via hepatitis B core protein. J Lipid Res. 2018;59:58-68. https://doi.org/10.1194/Jr.M079533.

11. Li YJ, Zhu P, Liang Y, Yin WG, Xiao JH. Hepatitis B virus induces expression of cholesterol metabolism-related genes via TLR2 in HepG2 cells. World J Gastroenterol. 2013;19:2262-9. https://doi.org/10.3748/wjg.v19.114.2262.

12. Kang SK, Chung TW, Lee JY, Lee YC, Morton RE, Kim CH. The hepatitis B virus $X$ protein inhibits secretion of apolipoprotein $B$ by enhancing the expression of $\mathrm{N}$-acetylglucosaminyltransferase III. J Biol Chem. 2004;279: 28106-12. https://doi.org/10.1074/jbc.M403176200.

13. Kim K, Kim KH, Kim HH, Cheong J. Hepatitis B virus X protein induces lipogenic transcription factor SREBP1 and fatty acid synthase through the activation of nuclear receptor LXRalpha. Biochem J. 2008;416:219-30. https://doi.org/10.1042/BJ20081336.

14. Bremer CM, Bung C, Kott N, Hardt M, Glebe D. Hepatitis B virus infection is dependent on cholesterol in the viral envelope. Cell Microbiol. 2009;11:24960. https://doi.org/10.1111/j.1462-5822.2008.01250.x.

15. Chu CM, Lin DY, Liaw YF. Does increased body mass index with hepatic steatosis contribute to seroclearance of hepatitis B virus (HBV) surface antigen in chronic HBV infection? Int J Obes. 2007;31:871-5. https://doi. org/10.1038/sj.ijo.0803479.

16. Funk A, Mhamdi M, Hohenberg $H$, Heeren J, Reimer R, et al. Duck hepatitis $B$ virus requires cholesterol for endosomal escape during virus entry. J Virol. 2008;82:10532-42. https://doi.org/10.1128/JVI.00422-08.

17. Ramcharran D, Wahed AS, Conjeevaram HS, Evans RW, Wang T, et al. Associations between serum lipids and hepatitis $\mathrm{C}$ antiviral treatment efficacy. Hepatology. 2010;52:854-63. https://doi.org/10.1002/hep.23796.

18. Pollock S, Nichita NB, Böhmer A, Radulescu C, Dwek RA, et al. Polyunsaturated liposomes are antiviral against hepatitis $B$ and $C$ viruses and HIV by decreasing cholesterol levels in infected cells. Proc Natl Acad Sci U S A. 2010;107:17176-81. https://doi.org/10.1073/pnas.1009445107.

19. Xun Z, Lin JP, Liu C, Huang JL, Shen Y, Chen Y, et al. Association of serum total cholesterol with pegylated interferon-a; treatment in HBeAg-positive chronic hepatitis B patients. Antivir Ther. 2019;24:85-93. https://doi.org/10.3851/IMP3282.

20. Wang GQ, Wang FS, Cheng J, Ren H, Zhuang H, et al. The guideline of prevention and treatment for chronic hepatitis B: a 2015 update. J Clin Hepatol. 2015;31:1941-60.

21. Organization WH. Hepatitis B. 2015. http://wwwwhoint/csr/disease/hepatitis/ whocdscsrlyo20022/en/index1html. Accessed 03 Aug 2015.

22. Schweitzer A, Horn J, Mikolajczyk RT, Krause G, Ott JJ. Estimations of worldwide prevalence of chronic hepatitis B virus infection: a systematic review of data published between 1965 and 2013. Lancet. 2015;386:154655. https://doi.org/10.1016/S0140-6736(15)61412-X.

23. WHO. Global Hepatitis Report 2017. 2019. https://www.who.int/hepatitis/ publications/globalhepatitis-report2017/en/. Accessed 3 Apr 2019.

24. Ghany MG. Current treatment guidelines of chronic hepatitis B: the role of nucleos $(t)$ ide analogues and peginterferon. Best Pract Res Clin Gastroenterol. 2017;31:299-309. https://doi.org/10.1016/j.bpg.2017.04.012.

25. Kim HY, Cho HK, Choi YH, Lee KS, Cheong J. Bile acids increase hepatitis B virus gene expression and inhibit interferon-alpha activity. FEBS J. 2010;277: 2791-802. https://doi.org/10.1111/j.1742-4658.2010.07695.x.

26. Lacy M, Atzler D, Liu R, Winther M, Weber C, Lutgens E. Interactions between dyslipidemia and the immune system and their relevance as putative therapeutic targets in atherosclerosis. Pharmacol Ther. 2019;193:5062. https://doi.org/10.1016/j.pharmthera.2018.08.012.

27. Papin J, Brennand A, Arbore G, Hohenstein B, Kamvissi V, Kemper C, et al. Dysregulation of the CD4(+) T cells lineage differentiation in dyslipidemic patients and impact of lipoprotein-apheresis treatment: a case study. Atheroscler Suppl. 2017;30:238-45. https://doi.org/10.1016/j.a therosclerosissup.2017.05.046

\section{Publisher's Note}

Springer Nature remains neutral with regard to jurisdictional claims in published maps and institutional affiliations.

\section{Ready to submit your research? Choose BMC and benefit from:}

- fast, convenient online submission

- thorough peer review by experienced researchers in your field

- rapid publication on acceptance

- support for research data, including large and complex data types

- gold Open Access which fosters wider collaboration and increased citations

- maximum visibility for your research: over $100 \mathrm{M}$ website views per year

At BMC, research is always in progress.

Learn more biomedcentral.com/submissions 